\title{
STUDY EPIDEMIOLOGI DENGAN PENDEKATAN ANALISIS SPASIAL TEMPORAL PADA KEJADIAN DEMAM BERDARAH DENGUE (DBD) DI KECAMATAN MASARAN KABUPATEN SRAGEN TAHUN 2016-2018
}

\author{
Dodiet Aditya Setyawan \\ Poltekkes Kemenkes Surakarta Jurusan Terapi Wicara
}

\begin{abstract}
Background: The high number of visits by sufferers of some environmental-based diseases to health service centers shows that the disease is still a serious problem in Indonesia, and one of them is Dengue Hemorrhagic Fever (DHF). Dengue Hemorrhagic Fever (DHF) in Sragen regency has become endemic, especially in the Masaran sub-district reportedly still an endemic area of dengue fever. Geographically, the endemicity of Dengue Hemorrhagic Fever (DHF) in an area can be described using Geographic Information Systems (GIS). Research Objectives: This study aims to provide an overview of the Spatial and Temporal Dengue Hemorrhagic Fever (DHF) distribution based on population density and rainfall factors as well as to provide a description of the endemicity of the area against DHF in Masaran District, Sragen Regency with the application of Geographic Information Systems (GIS). Methods: The design of this study was Observational Analytic with Crossectional approach using Geographic Information Systems (GIS) modeling. The data used are secondary data about the incidence of DHF from the Sragen District Health Office in 2016-2018. The research subjects were determined by a Registry Based Study approach with a saturated sampling technique. The collected data will be analyzed descriptively by displaying a frequency distribution table, bivariate analysis with the Pearson Product Moment test and spatial-temporal analysis using the Geographic Information System (GIS) function. Results: The results of this study indicate that the spatial distribution of Dengue Hemorrhagic Fever (DHF) events is distributed randomly to all regions in Masaran District, Regency. The incidence of DHF in Masaran Subdistrict, Sragen Regency was related to Rainfall $(p=0.006)$ with a negative correlation direction $(r=-$ 0.741). The incidence of DHF in The Masaran Subdistrict, Sragen Regency was not related to population density $(p=0.839)$. Spatially-Temporal shows that there are 6 Villages in Masaran Subdistrict, Sragen Regency which are endemic areas of Dengue Hemorrhagic Fever (DBD), namely Sepat, Dawungan, Masaran, Jati, Pringanom and Krikilan villages. Conclusion: Incidence of Dengue Hemorrhagic Fever (DHF) in Masaran Subdistrict, Sragen Regency is related to Rainfall, where low rainfall tends to increase the incidence of DHF. During 2016-2018 in Masaran Subdistrict, Sragen Regency, there were 6 villages which were endemic areas of DHF, namely Sepat, Dawungan, Masaran, Jati, Pringanom and Krikilan villages.
\end{abstract}

Keywords: Dengue Hemorrhagic Fever (DHF), Spatial-Temporal Analysis, GIS 


\section{PENDAHULUAN}

Penyakit yang berhubungan dengan lingkungan masih merupakan masalah kesehatan yang selalu ada di tengah tengah masyarakat Indonesia. Hal ini terlihat dari masih tingginya kunjungan penderita beberapa penyakit tersebut ke pusat - pusat pelayanan kesehatan dimana salah satunya adalah penyakit Demam Berdarah Dengue (DBD).(Ditjen P2PL Kemenkes RI, 2013). Penyakit Demam Berdarah Dengue di kabupaten Sragen sudah menjadi penyakit endemis setiap tahun pada beberapa kecamatan dan dilaporkan masih terdapat penderita yang meninggal dunia akibat penyakit tersebut. Secara geografis, endemisitas penyakit Demam Berdarah Dengue (DBD) di suatu wilayah dapat digambarkan dengan menggunakan Sistem Informasi Geografis (SIG). SIG dalam perkembangannya dewasa ini telah menjadi alat yang memiliki dampak positif dalam proses perencanaan berbasis komunitas dan pembuatan keputusan ilmiah untuk aktivitas pengembangan program. SIG merupakan sebuah sistem yang mampu membangun, memanipulasi dan menampilkan informasi yang mempunyai referensi geografis. (Ramadona dan Kusnanto, 2011)

\section{METODE PENELITIAN}

Desain penelitian ini adalah Analitik Observasional dengan pendekatan Cross Sectional menggunakan pemodelan SIG dan analisis spasial-temporal untuk mendapatkan gambaran distribusi secara spasial dan secara temporal terhadap kasus DBD serta hubungan spasial faktorfaktor risiko kejadian penyakit DBD di Kecamatan Masaran, Kabupaten Sragen (Sugiyono, 2018). Data yang digunakan merupakan data sekunder tentang angka kejadian DBD di Wilayah Puskesmas Kecamatan Masarann berdasarkan laporan dari Dinas Kesehatan Kabupaten Sragen Tahun 2016-2018. Subyek dalam penelitian ini adalah kejadian Demam Berdarah Dengue (DBD) di wilayah Puskesmas Kecamatan Masaran Kabupaten Sragen tahun 2016-2017 yang ditetapkan dengan pendekatan Registry Based Study (Budiman, 2011). Adapun tenik sampling yang digunakan adalah sampling jenuh. (Murti, B.,2010). Analisis Data dilakukan secara deskriptif, analisis bivariat dengan uji Pearson Product Moment dan analisis spasial-temporal menggunakan fungsi overlay dengan pemodelan Sistem Informasi Geografis (SIG) menggunakan software ArcGIS. (Prahasta, E., 2009)

\section{HASIL PENELITIAN}

\section{Analisis Deskriptif}

Tabel 1. Gambaran Kejadian DBD Menurut Rata-Rata Kepadatan Penduduk di Kecamatan Masaran Tahun 2016-2018

\begin{tabular}{|c|c|c|c|c|c|c|c|c|}
\hline \multirow{2}{*}{ DESA } & \multicolumn{3}{|c|}{ KASUS DBD } & \multirow{2}{*}{$\begin{array}{l}\text { JML } \\
\text { DBD }\end{array}$} & \multicolumn{3}{|c|}{ KEPDTN PDDK } & \multirow{2}{*}{$\begin{array}{l}\text { RATA }^{2} \\
\text { KPDTN }\end{array}$} \\
\hline & 2016 & 2017 & 2018 & & 2016 & 2017 & 2018 & \\
\hline Sidodadi & 12 & 1 & $\mathbf{0}$ & 13 & 1262 & 1679 & 1565 & 1502 \\
\hline Karangmalang & 9 & $\mathbf{0}$ & $\mathbf{0}$ & 9 & 1845 & 2124 & 1910 & 1960 \\
\hline Krebet & 14 & 1 & $\mathbf{0}$ & 15 & 1447 & 1516 & 1476 & 1480 \\
\hline Sepat & 10 & 1 & 1 & 12 & 1579 & 1566 & 1630 & 1592 \\
\hline Jirapan & 8 & 2 & $\mathbf{0}$ & 10 & 1467 & 1463 & 1620 & 1517 \\
\hline Gebang & 10 & $\mathbf{0}$ & $\mathbf{0}$ & 10 & 1530 & 1348 & 1376 & 1418 \\
\hline Dawungan & 5 & 5 & 1 & 11 & 1519 & 1457 & 1436 & 1471 \\
\hline Masaran & 10 & 1 & 1 & 12 & 2833 & 2443 & 2522 & 2599 \\
\hline
\end{tabular}




\begin{tabular}{lcccccccc} 
Jati & $\mathbf{1 0}$ & $\mathbf{3}$ & $\mathbf{1}$ & $\mathbf{1 4}$ & 1976 & 2094 & 2102 & $\mathbf{2 0 5 7}$ \\
Kliwonan & $\mathbf{3}$ & $\mathbf{0}$ & $\mathbf{0}$ & $\mathbf{3}$ & 1563 & 1743 & 1796 & $\mathbf{1 7 0 1}$ \\
Pilang & $\mathbf{1}$ & $\mathbf{0}$ & $\mathbf{4}$ & $\mathbf{5}$ & 2114 & 1905 & 1965 & $\mathbf{1 9 9 5}$ \\
Pringanom & $\mathbf{8}$ & $\mathbf{2}$ & $\mathbf{1}$ & $\mathbf{1 1}$ & 1229 & 1317 & 1418 & $\mathbf{1 3 2 1}$ \\
Krikilan & $\mathbf{5}$ & $\mathbf{1}$ & $\mathbf{1}$ & $\mathbf{7}$ & 1746 & 1645 & 1568 & $\mathbf{1 6 5 3}$ \\
\hline
\end{tabular}

1. Gambaran Kejadian DBD Menurut Rata-Rata Kepadatan Penduduk di Kecamatan Masaran Tahun 20162018.

Data hasil penelitian dari Dinas Kesehatan Kabupaten Sragen tentang angka kejadian DBD dan kepadatan penduduk di Kecamatan Masaran yang diperoleh dari Badan Pusat Statistik Kabupaten Sragen pada tahun 2016-2018 (BPS Kab. Sragen, 2019) sebagaimana terdapat pada tabel 1, menunjukkan bahwa: angka kejadian DBD di Kecamatan Masaran paling banyak terjadi padat tahun
2016 yaitu sebesar 105 kasus, selanjutnya padamtahun 2017 turun menjadi 17 kasus dan paling sedikit terjadi pada Tahun 2018 yaitu sebanyak 10 kasus. Desa yang terdapat kasus DBD selama 3 tahun berturut-turut terjadi di desa Sepat, Dawungan, Masaran, Jati, Pringanom dan Krikilan.Sedangkan rata-rata tingkat kepadatan penduduk dalam 3 tahun di Kecamatan Masaran yang paling tinggi terdapat di desa/kelurahan Masaran, Jati, Pilang dan Karangmalang

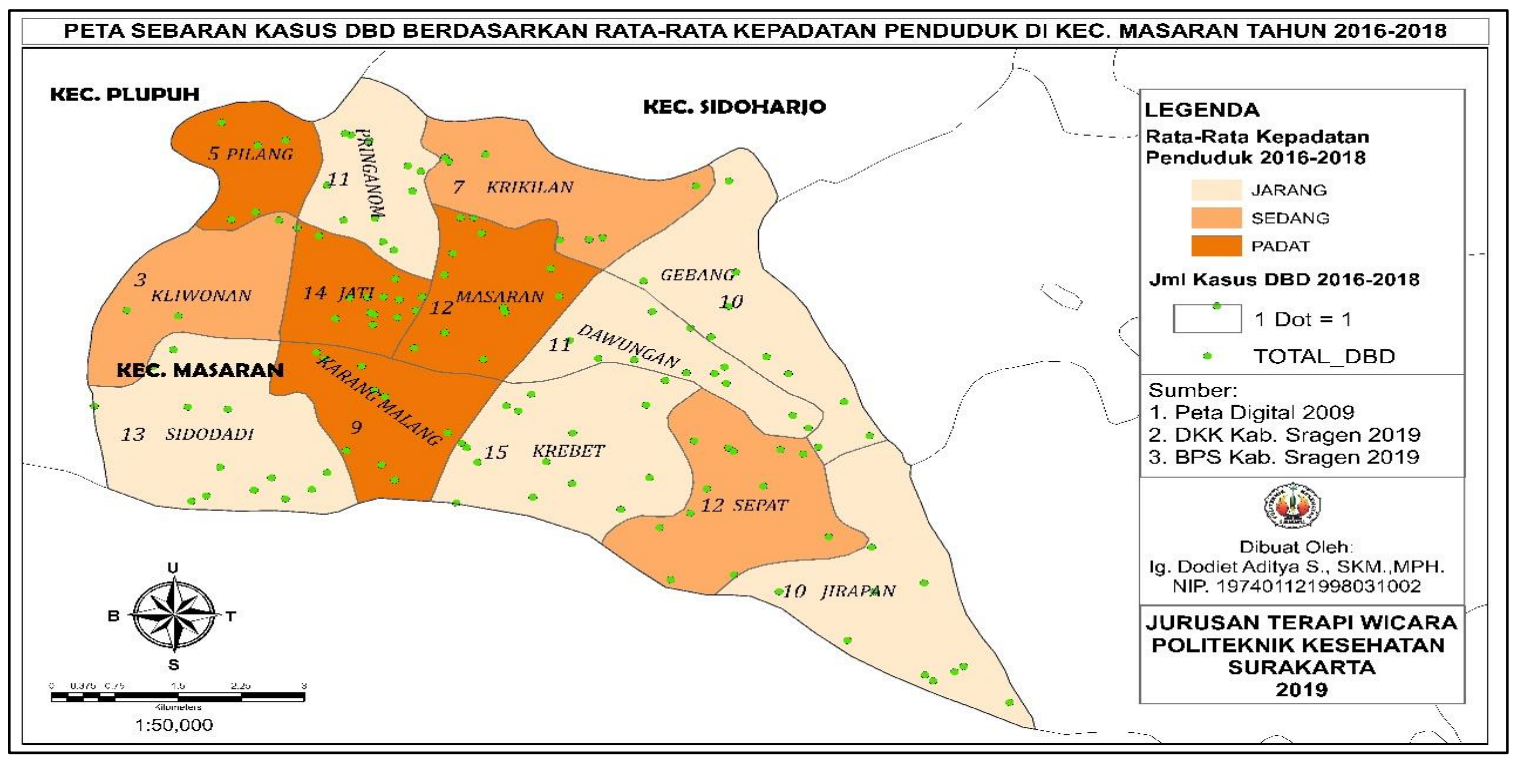

Gambar 1. Peta Sebaran Kasus DBD Menurut Rata-Rata Kepadatan Penduduk di Kecamatan Masaran Tahun 2016-2018 
2. Gambaran Spasial Kejadian DBD Menurut Rata-Rata Kepadatan Penduduk di Kecamatan Masaran Tahun 2016-2018.

Hasil dari penelitian yang ditampilkan pada gambar 1 tersebut diatas menunjukkan bahwa sebaran kasus DBD di Kecamatan Masaran selama 3 tahun terakhir, yaitu Tahun 2016-2018 terjadi secara acak dan merata di semua Desa/Kelurahan. Jumlah Angka Kejadian Kasus DBD yang terbanyak justru terdapat di Desa Krebet yang merupakan desa dengan tingkat kepadatan penduduk rendah.

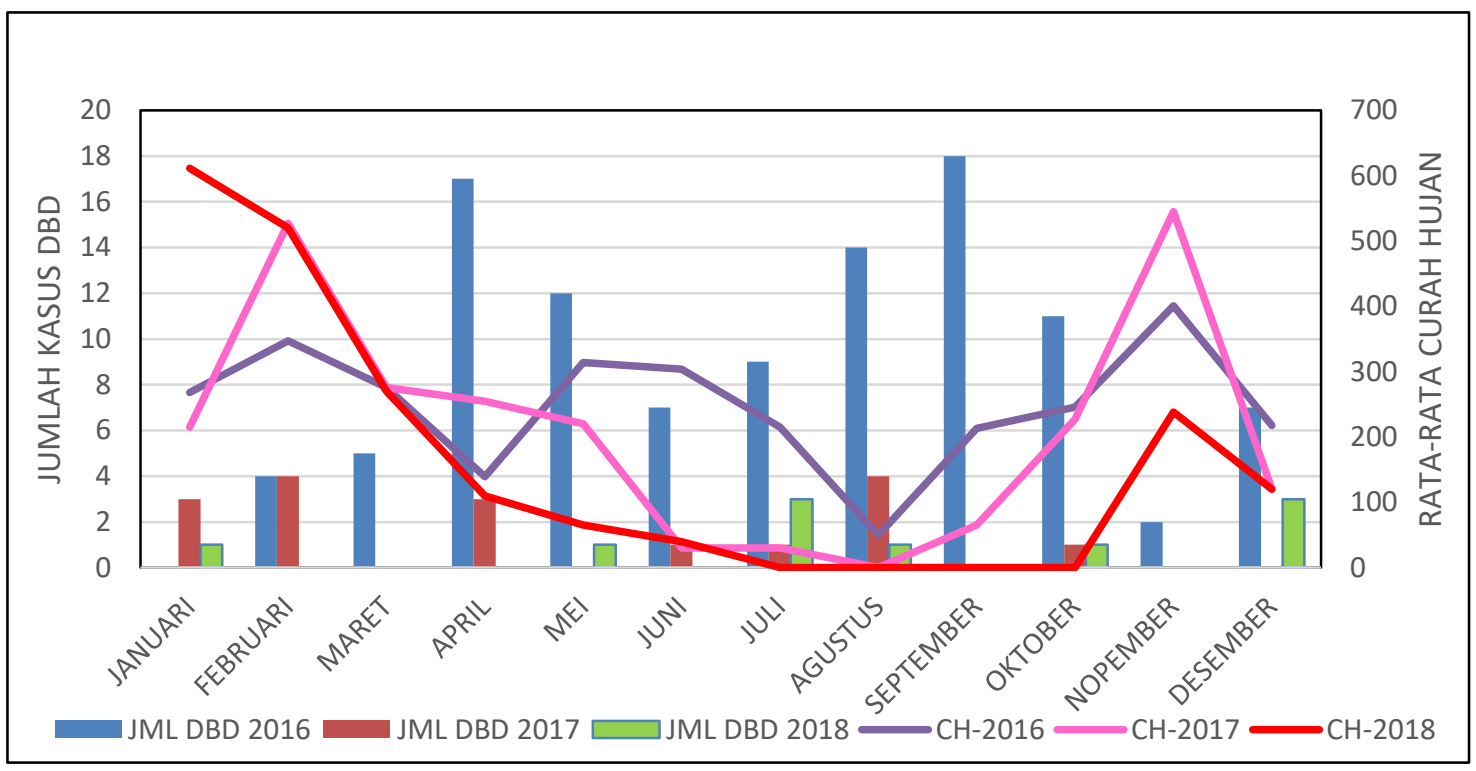

Grafik 1. Gambaran Temporal Kejadian DBD Menurut Rata-Rata Curaj Hujan Tahun 2016-2018

3. Gambaran Temporal Kejadian DBD menurut Rata-Rata Curah Hujan Tiap Bulan di Kecamatan Masaran Tahun 2016-2018.

Bahwa rata-rata jumlah kasus DBD di kecamatan Masaran selama 3 tahun terakhir paling banyak terjadi di bulan April, Agustus dan September, yang tergambar pada grafik.1 Selanjutnya rata-rata curah hujan yang tertinggi selama 3 tahun terakhir terjadi pada bulan Januari, Februari, dan November . Pada grafik 1 juga menunjukan bahwa pada bulan Januari, Februari dan November yang merupakan waktu dimana rata-rata curah hujannya tinggi, justru memperlihatkan rata-rata kejadian kasus DBD yang rendah atau sedikit. Sedangakan pada bulan-bulan dimana rata-rata curah hujannya sedikit sampai sedang, angka kejadian Demam Berdarah Dengue, rata-rata masuk dalam kategori sedang sampai tinggi.

\section{Analsis Bivariat.}

Analisis bivariat dilakukan untuk mengetahui hubungan antara variabel bebas dengan variabel terikat. (Dahlan, MS., 2010). Analisis Statistik dilakukan dengan menggunakan teknik Uji Pearson Product Momment dengan hasil sebagai berikut: 
Tabel 2. Hasil Analisis Bivariat

\begin{tabular}{llc}
\hline \multicolumn{1}{c}{ Variabel } & $\begin{array}{c}\text { Kepadatan } \\
\text { Penduduk }\end{array}$ & $\begin{array}{c}\text { Rata-Rata } \\
\text { Curah Hujan }\end{array}$ \\
\hline Kejadian $D B D$ & & \\
\hline$\bullet \quad$ Nilai $\boldsymbol{P}$ & $\mathbf{0 , 8 3 9}$ & $\mathbf{0 , 0 0 6}$ \\
Koefisien & 0,063 & $-0,741$ \\
\hline
\end{tabular}

Berdasarkan hasil analisis bivariat tersebut, maka hubungan antar variabel dapat dijelaskan sebagai berikut:

1. Hubungan antara Kejadian Demam Berdarah Dengue (DBD) dengan Kepadatan Penduduk.

Dari hasil analisis bivariat pada tabel 2 di atas diperoleh nilai $p$ sebesar 0,839 $(\mathrm{p}>0,05)$. Hal tersebut berarti secara statistik tidak terdapat hubungan yang bermakna antara kejadian kasus Demam Berdarah Dengue (DBD) dengan kepadatan penduduk di Kecamatan Masaran Kabupaten Sragen pada Tahun 20162018.

2. Hubungan antara Kejadian Demam Berdarah Dengue (DBD) dengan Rata-Rata Curah Hujan Per Bulan.

Dari hasil analisis bivariat pada tabel 2 di atas diperoleh nilai $p$ sebesar 0,006 $(p<0,05)$. Hal tersebut berarti secara statistik terdapat hubungan yang bermakna antara kejadian kasus Demam Berdarah Dengue (DBD) dengan Rata-Rata Curah Hujan di Kecamatan Masaran Kabupaten Sragen pada Tahun 20162018. Selanjutnya Koefisien Korelasi menunjukkan nilai sebesar $-0,741$ yang berarti bahwa hubungan antara Kejadian Demam Berdarah Dengue dengan Rata-Rata Curah Hujan termasuk dalam kategori Kuat dengan arah Negatif. Hal ini berarti bahwa semakin sedikit atau rendah curah hujan maka angka kejadian Demam Berdarah Dengue semakin tinggi atau banyak. (Fajar, I., 2009).

\section{Analisis Spasial-Temporal Kejadian Demam Berdarah Dengue (DBD) Tahun 2016-2018.}

Analisis Spasial Temporal dimaksudkan untuk mendapatkan gambaran sebaran kasus DBD di Kecamatan Masaran dari Tahun 2016 sampai dengan tahun 2018. Dengan didapatkannya gambaran persebaran kasus DBD selama kurun waktu 3 tahun berturut-turut, maka akan dapat mengidentifikasi wilayah Desa/ Kelurahan di Kecamatan Masaran yang merupakan daerah endemik terhadap penyakit Demam Berdarah Dengue (DBD). (Harimurti, N.K., 2007). Analisis Spasial Temporal Angka Kejadian DBD di Kecamatan Masaran Kabupaten Sragen Tahun 2016-2018 dapat dilihat pada Gambar berikut ini: 


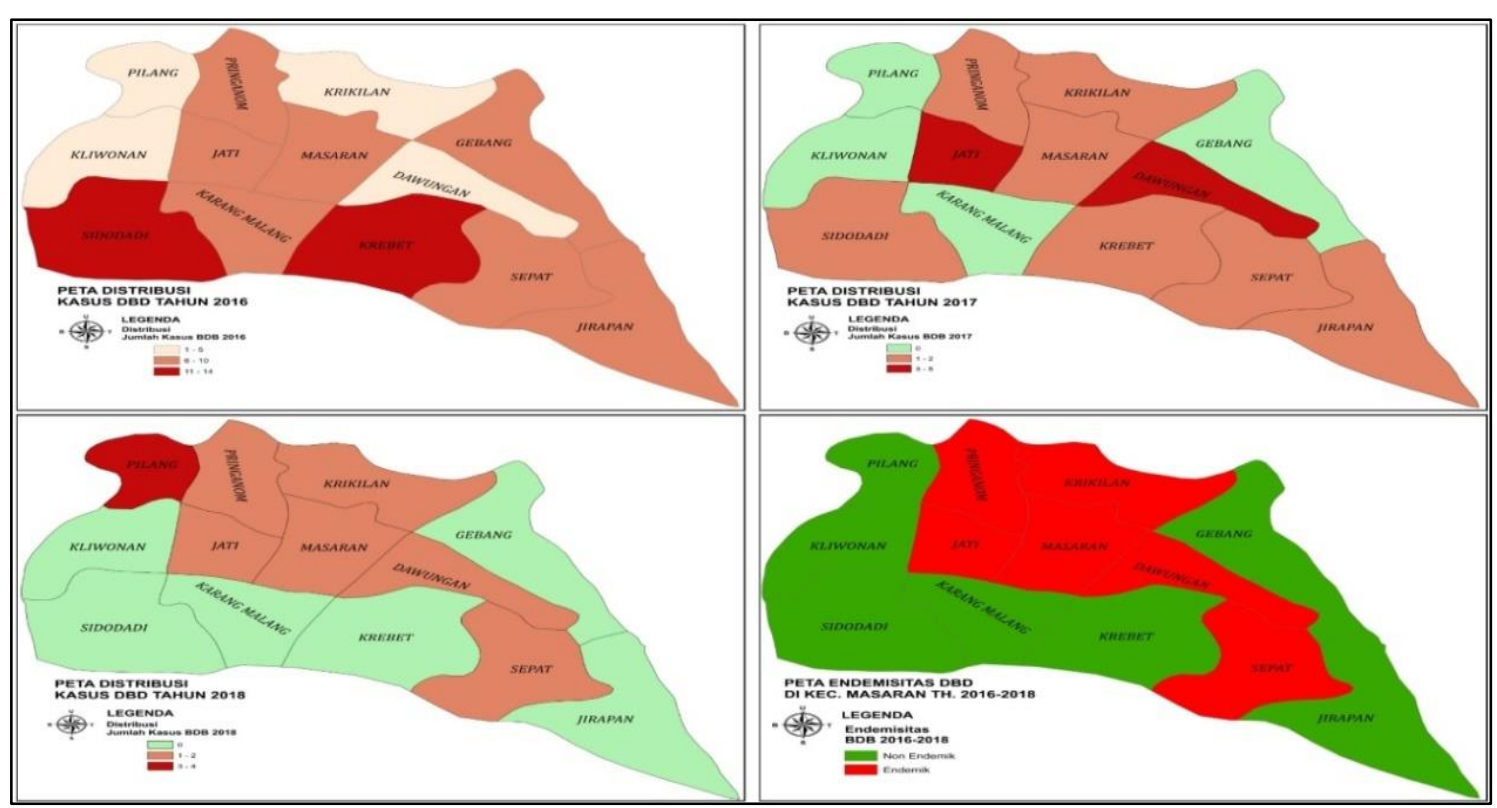

Gambar 2. Peta Gambaran Spasial-Temporal Kejadian DBD di Kecamatan Masaran 2016-2019

Berdasarkan hasil penelitian yang disajikan dalam Gambar 2 tersebut, didapatkan data tentang perkembangan jumlah kejadian Demam Berdarah Dengue (DBD) di Kecamatan Masaran Kabupaten Sragen mempunyai kecenderungan mengalami penurunan, walaupun pada Tahun 2018 angka kejadian Demam Berdarah Dengue (DBD) mengalami kenaikan kembali. Dari gambaran peta Spasial-Temporal tersebut menunjukkan bahwa masih terdapat 6 Desa di Kecamatan Masaran yang merupakan daerah Endemik Demam Berdarah Dengue. Desa- desa tersebut antara lain desa Sepat, Dawungan, Masaran, Jati, Pringanom dan Krikilan.

\section{PEMBAHASAN}

Hubungan antara Kejadian Demam Berdarah Dengue (DBD) dengan Kepadatan Penduduk.

Dari hasil analisis bivariat pada tabel 2 di atas diperoleh nilai $p$ sebesar $0,839$ ( $p>0,05)$. Hal tersebut berarti secara statistik tidak terdapat hubungan yang bermakna antara kejadian kasus Demam Berdarah Dengue (DBD) dengan kepadatan penduduk di Kecamatan Masaran Kabupaten Sragen pada Tahun 2016-2018.

Hasil ini sesuai dengan penelitian yang dilakukan di kota Padang oleh Handayani, Fannya, Rosa, \& Inge (2017), yang membuktikan bahwa tidak terdapat korelasi antara kepadatan penduduk dengan kejadian Demam Berdarah Dengue.

Hasil penelitian ini tidak menunjukkan adanya hubungan antara kepadatan penduduk dengan kejadian DBD dikarenakan sebaran jumlah penduduk di Kecamatan Masaran, Kabupaten Sragen sangat variatif, dimana kepadatan penduduk tidak hanya terdapat pada satu wilayah perkotaan saja, tetapi juga terdapat di beberapa wilayah pedesaan. Kepadatan penduduk di Kecamatan Masaran, Kabupaten Sragen hampir sama dibeberapa Desa/ Kelurahan 
sehingga menyebabkan peran dari kepadatan penduduk tersebut terhadap angka kejadian DBD menjadi tidak bermakna. Selain itu kejadian kasus DBD di Kecamatan Masaran, Kabuapaten Sragen dari tahun 2016-2018 terdespersi secara acak ke semua Desa/ Kelurahan di Kecamatan Masaran. Kabupaten Sragen.

\section{Hubungan antara Kejadian Demam Berdarah Dengue (DBD) dengan Rata- Rata Curah Hujan Per Bulan.}

Dari hasil analisis bivariat diperoleh nilai $p=0,006(\mathrm{p}<0,05)$ dengan Koefisien Korelasi $=-0,741$. Hal tersebut berarti secara statistik terdapat hubungan yang bermakna antara kejadian kasus Demam Berdarah Dengue (DBD) dengan RataRata Curah Hujan di Kecamatan Masaran Kabupaten Sragen pada Tahun 2016-2018 dengan arah Negatif dan dalam kategori Kuat. Hal ini menunjukkan arah yang berlawanan antara Kejadian DBD dengan Curah Hujan, yaitu semakin sedikit atau rendah curah hujan maka angka kejadian Demam Berdarah Dengue akan semakin tinggi atau banyak. (Dahlan, M.S., 2017).

Curah Hujan berpengaruh secara langsung terhadap kejadian kasus Demam Berdarah Dengue (DBD). Tinggi rendahnya curah hujan dapat mempengaruhi keberadaan tempat perkembangbiakan nyamuk Aedes aegypti yang merupakan vector penularan penyakit DBD. (Arianti \& Musadad, 2012). Curah hujan yang tinggi dapat menyebabkan debit air di longkungan sekitar menjadi lebih tinggi pula auatu bahkan dapat terjadi banjir. Hal ini dapat menghanyutkan tempat untuk berkembang biaknya nyamuk Aedes aegypti yang menyebabkan populasi nyamuk akan berkurang. Sebaliknya apabila curah hujan sedikit akan menyebabkan bertambahnya tempat perkembangbiakan nyamuk dan meningkatkan populasinya. virus dari satu manusia ke manusia lain (Phillips, 2008).

Curah hujan yang rendah sampai sedang, dapat mengakibatkan air hujan menggenang di suatu wadah atau media yang menjadi tempat perkembang-biakan nyamuk yang aman seperti cekungan di pagar bambu, pepohonan, kaleng bekas, ban bekas, talang rumah dan sebagainya. Hal ini akan mengakibatkan tersedianya air dalam media yang selanjutnya dapat menyebabkan telur nyamuk dapat menetas dan setelah $10-12$ hari akan berubah menjadi nyamuk yang dapat menularkan penyakit DBD. (Solihin, 2004 dalam Arianti \& Musadad, 2012).

\section{KESIMPULAN DAN SARAN}

Angka Kejadian Kasus DBD di Kecamatan Masaran, Kabupaten Sragen dipengaruhi oleh Rata-rata Curah Hujan $(p=0,006)$ dengan arah negatif ( $\mathrm{r}=-$ $0,741)$ yang menyimpulkan bahwa curah hujan yang rendah dapat meningkatkan angka kejadian DBD.

Analisis Spasial Temporal terhadap Kejadian Penyakit Demam Berdarah Dengue (DBD) di Kecamatan Masaran, Kabupaten Sragen menunjukkan bahwa terdapat 6 Desa di Kecamatan Masaran yang merupakan daerah Endemik Demam Berdarah Dengue. Desa- desa tersebut antara lain desa Sepat, Dawungan, Masaran, Jati, Pringanom dan Krikilan.

Bagi Puskesmas dan Dinas Kesehatan perlu adanya kegiatan Surveilans vektor penyakit dan kasus Demam Berdarah Dengue yang lebih intensif terutama di daerah endemic DBD.

Perlu peningkatan kesadaran masyarakat dalam pengelolaan lingkungan yang lebih baik terutama di desa Sepat, Dawungan, Masaran, Jati, Pringanom dan 
Krikilan yang merupakan daerah endemic DBD.

Perlu dilakukan kampanye Pemberantasan Sarang Nyamuk (PSN) secara kontinyu dan lebih intensif kepada masyarakat agar angka kejadian DBD dapat semakin ditekan.

\section{DAFTAR RUJUKAN}

Ariati, J., \& Musadad, D. A. 2012. Kejadian Demam Berdarah Dengue (DBD) dan Faktor Iklim di Kota Batam, Provinsi Kepulauan Riau. Jurnal Ekologi Kesehatan, 11, 279286. Retrieved from http://ejournal.litbang.depkes.go.id/i ndex.php/jek/article/view/3831

Budiman. (2011). Penelitian Kesehatan. PT. Refika Aditama. Bandung.

BPS Kab. Sragen. 2019. Kabupaten Sragen Dalam Angka 2019. https://sragenkab.bps.go.id/publicati on/2019/08/16/9bfc353613f5655743 29a044/kabupaten-sragen-dalamangka-2019.html

Dahlan, M.S. 2010. Statistik Untuk Kedokteran Dan Kesehatan : Deskriptif, Bivariat dan Multivariat. Salemba Medika. Jakarta.

Ditjen P2PL Kemenkes RI. 2013. Informasi Pengendalian Penyakit dan Penyehatan Lingkungan. Jakarta. Kementerian Kesehatan. Available at: http://pppl.depkes.go.id/berita?id=1 283. Diakses tanggal 15 Januari 2014.

Fajar, I., dkk.,2009. Statistika Untuk Praktisi Kesehatan. Edisi Pertama. Graha Ilmu. Yogyakarta.
Handayani, S., Fannya, P., Rosa, S. H., \& Inge Angelia. (2017). Analisis Spasial Temporal Hubungan Kepadatan Penduduk Dan Ketinggian Tempat Dengan Kejadian DBD Kota Padang. Jurnal Kesehatan Medika Saintika, 8. https://jurnal.syedzasaintika.ac.id/in dex.php/medika/article/view/54/pdf -1

Harimurti, N.K. 2007. Analisis Spasial dan Temporal Kasus Demam Berdarah Dengue di Kota Yogyakarta. Skripsi. Fakultas Kedokteran Universitas Gadjah Mada. Yogyakarta. Tidak dipublikasikan.

Murti, B. 2010. Desain dan Ukuran Sampel untuk Penelitian Kuantitatif dan Kualitatif di Bidang Kesehatan. Yogyakarta. Gadjah Mada University Press.

Phillips, M. L. 2008. Dengue Reborn: Widespread Resurgence of a Resilient Vector. Environmental Health Perspectives, 116(9), 382388.

https://doi.org/10.1289/ehp.116a382

Prahasta, E. 2009. Sistem Informasi Geografis : Konsep-Konsep Dasar (Perspektif Geodesi \& Geomatika). Informatika. Bandung.

Ramadona, A.L. \& Kusnanto, H. 2011. Open Source GIS : Aplikasi Quantum GIS Untuk Sistem Informasi Lingkungan. BPFE. Yogyakarta.

Sugiyono, 2017. Metodologi Penelitian Kuantitatif, Kualitatif dan R \& D. CV. Alfabeta. Bandung. 